\title{
Synthetic Life: \\ Our Hybrid Future
}

\section{Jenna Rickus}

Agricultural \& Biological Engineering

Biomedical Engineering

Purdue University

Share your thoughts and ideas...

text M5672 + your message 765-560-4177

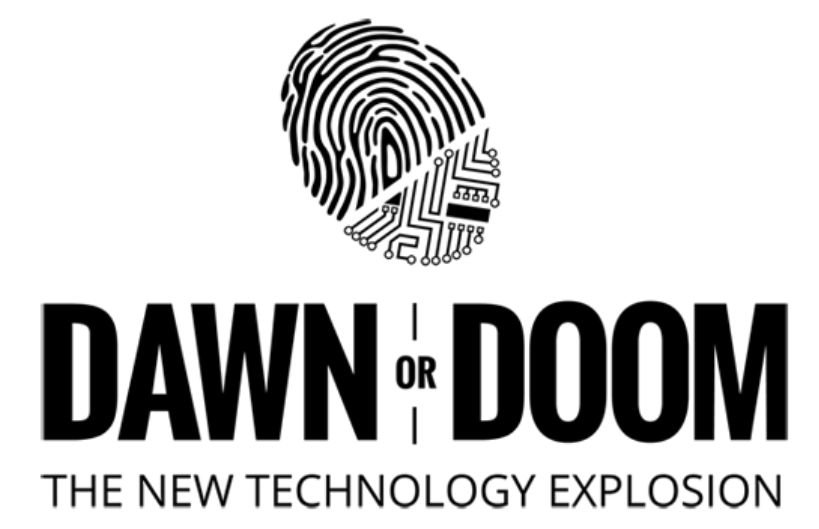




\section{What is Synthetic Life?}

What is Hybrid Technology? 


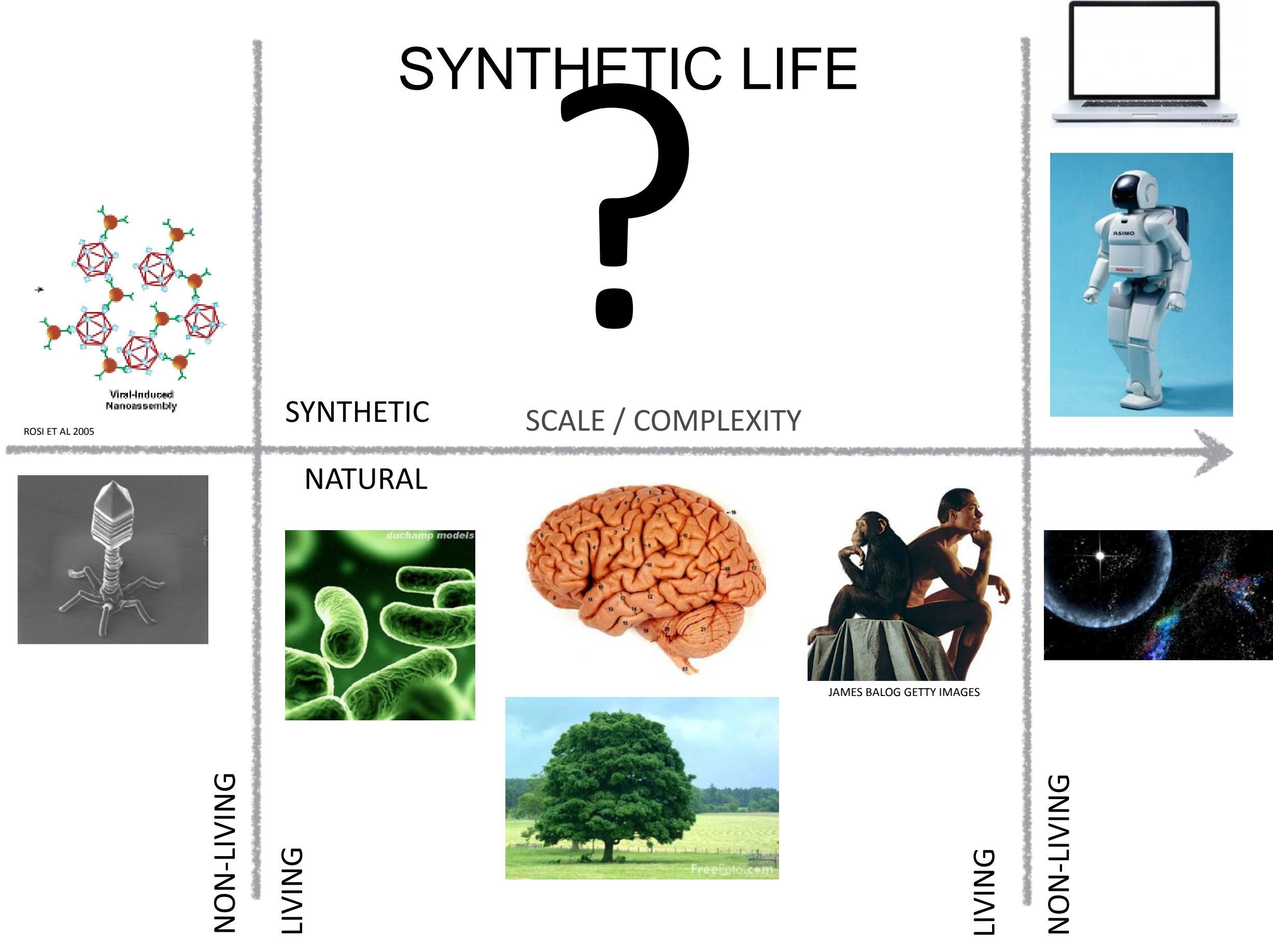




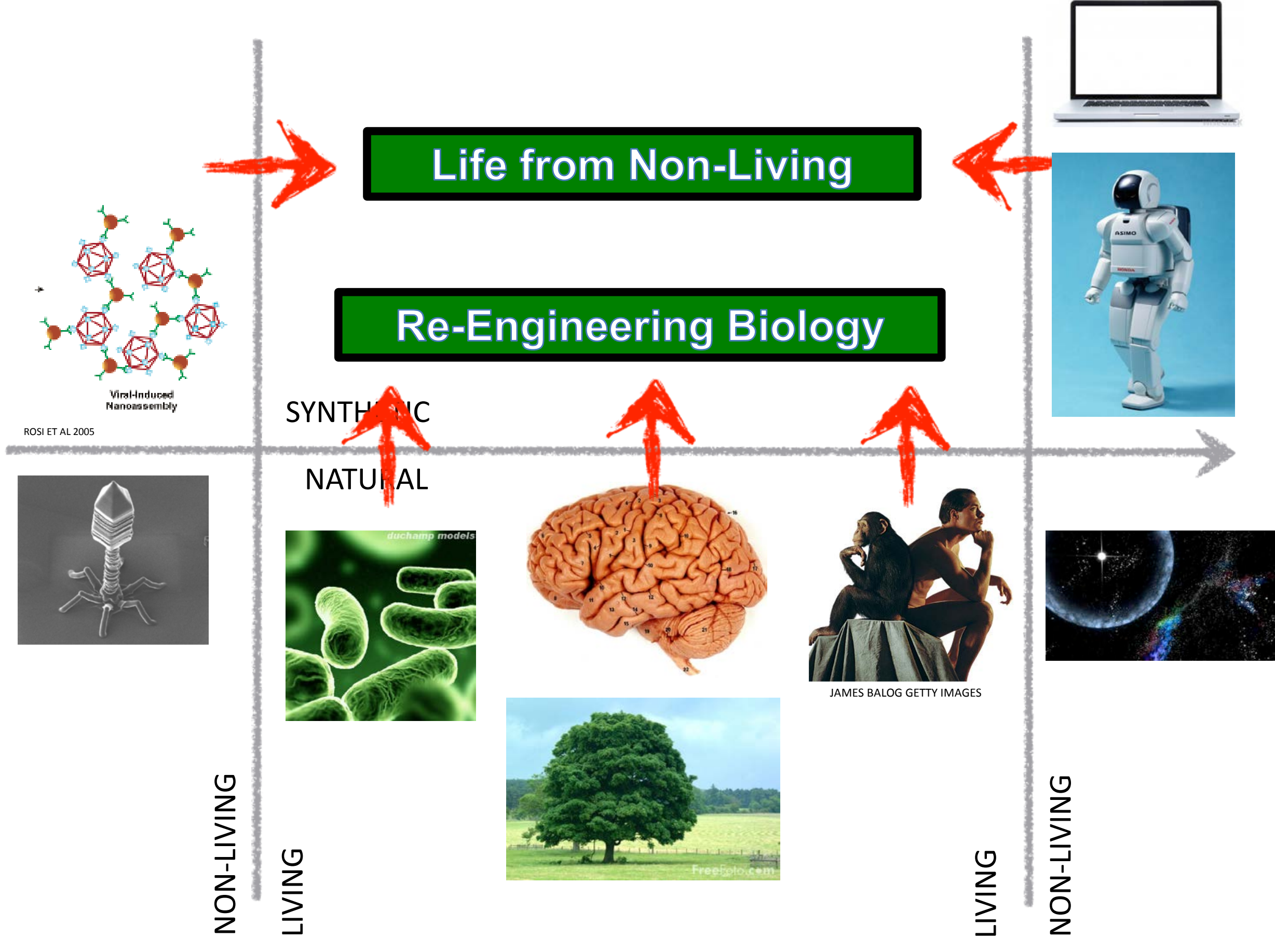




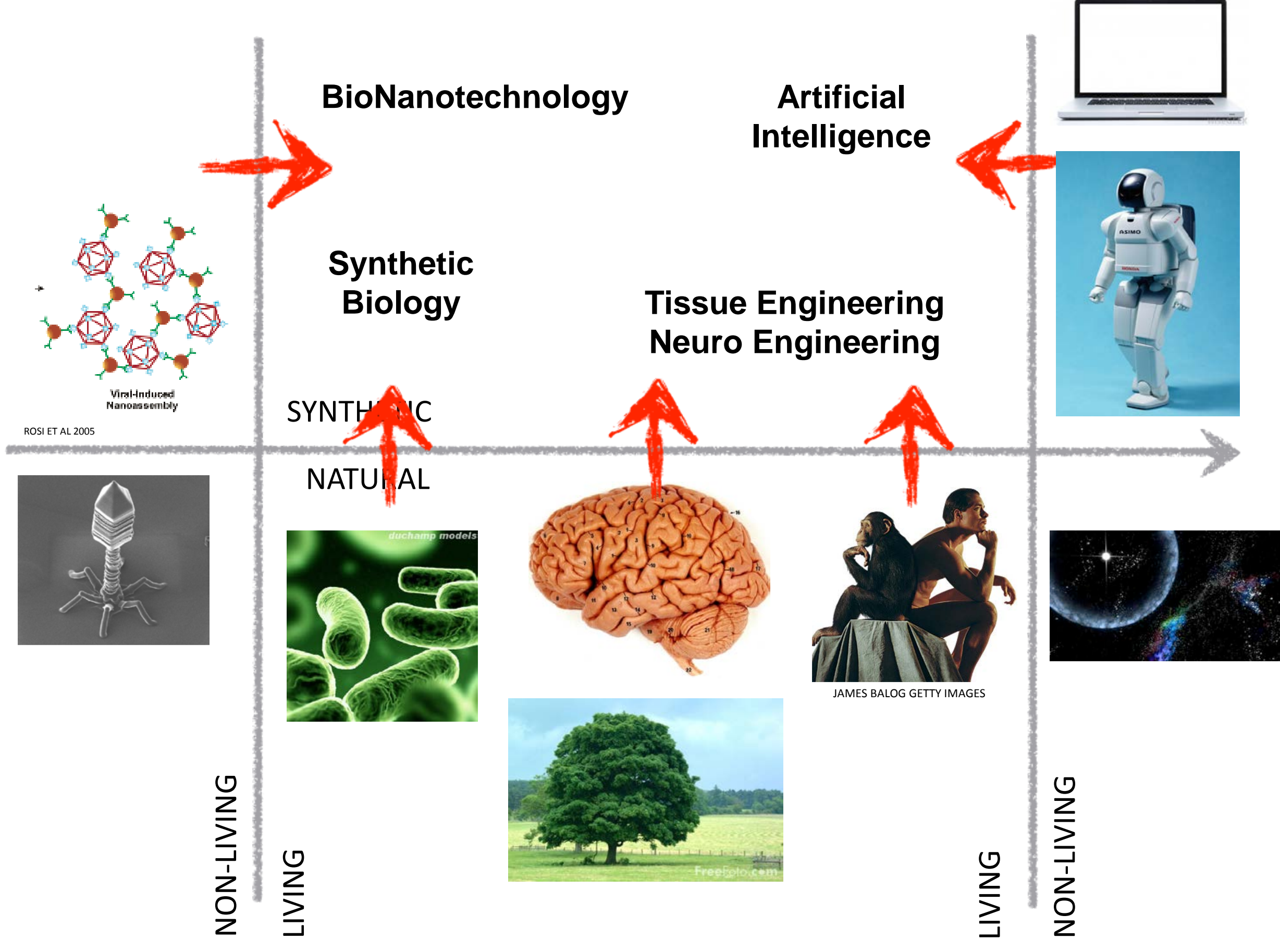




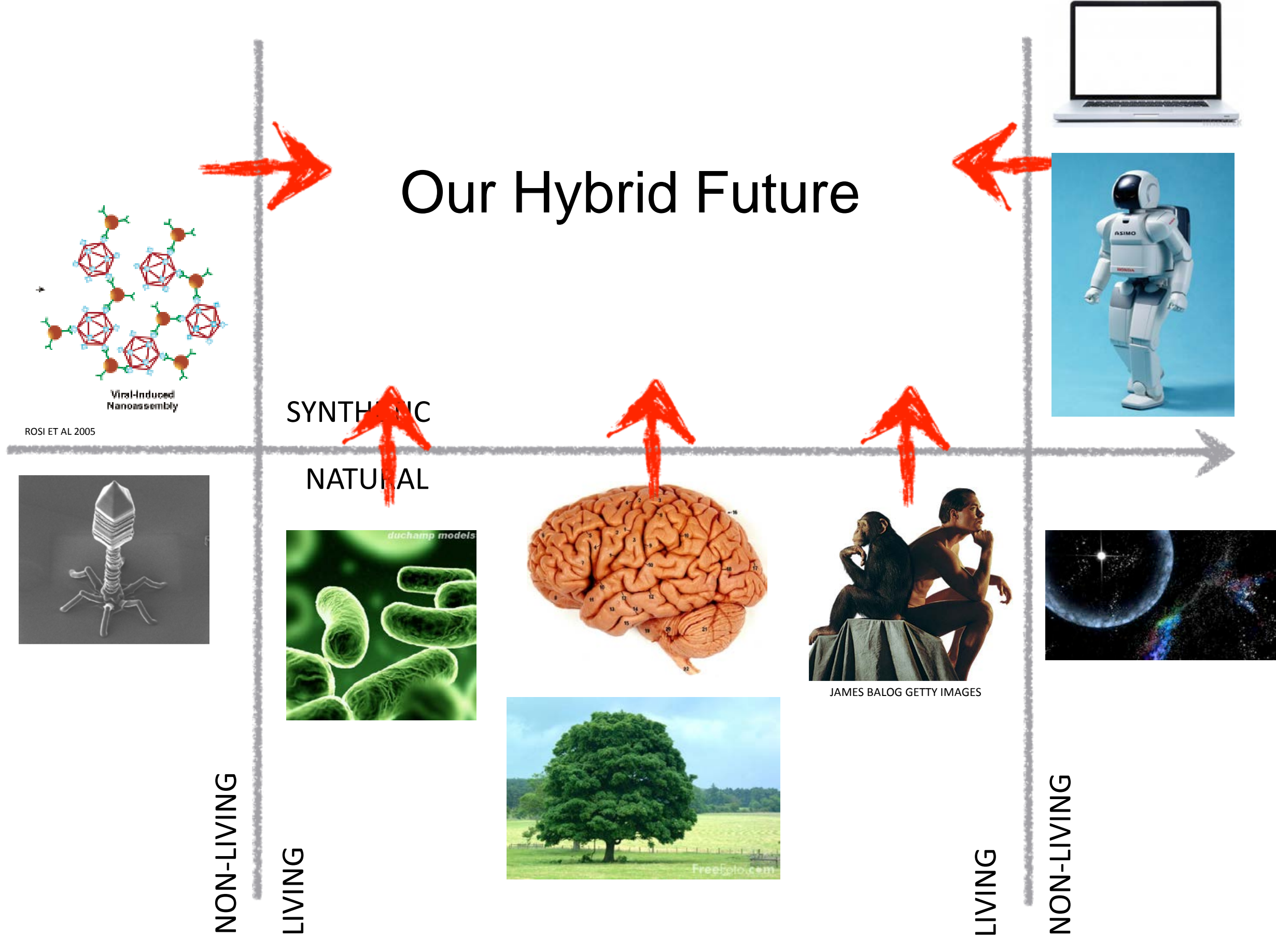




\section{Engineered}
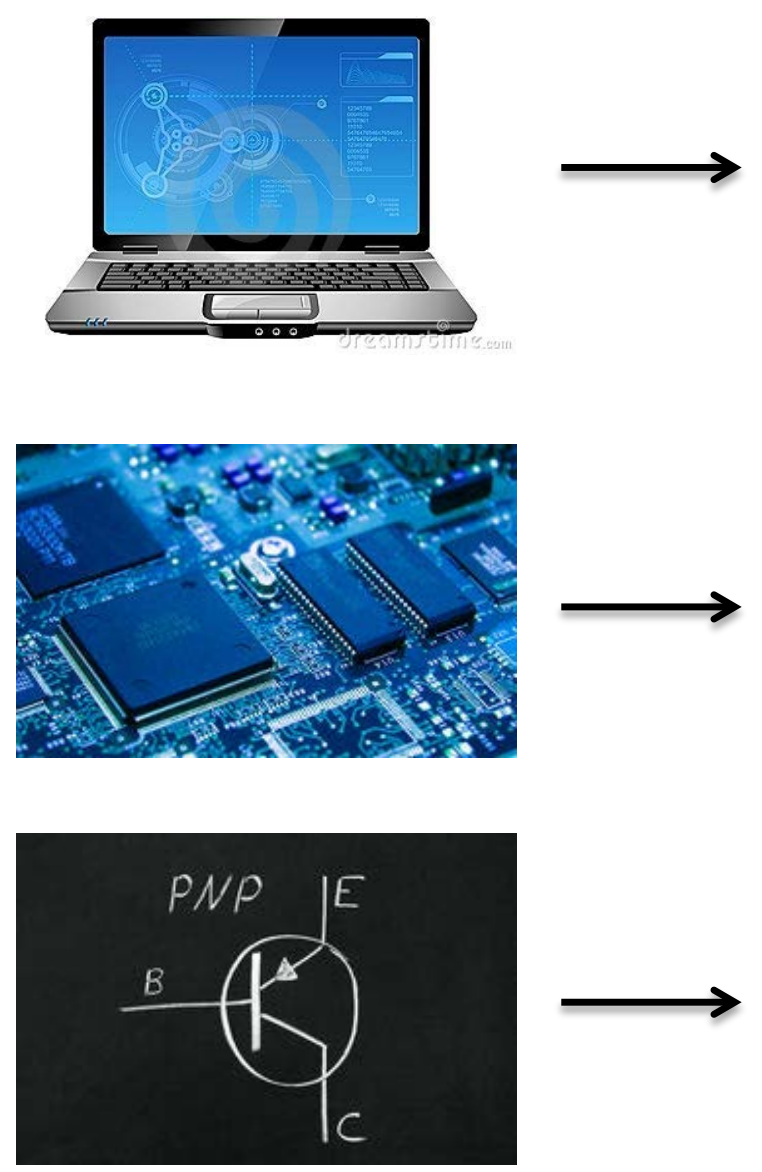

$\mathrm{Si}$

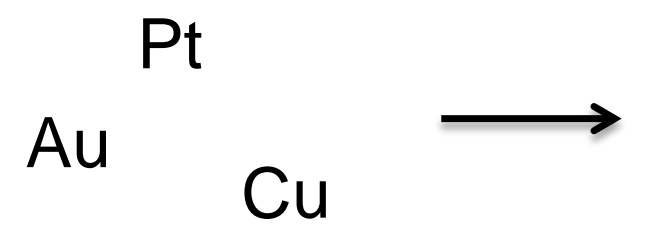

Hybrid
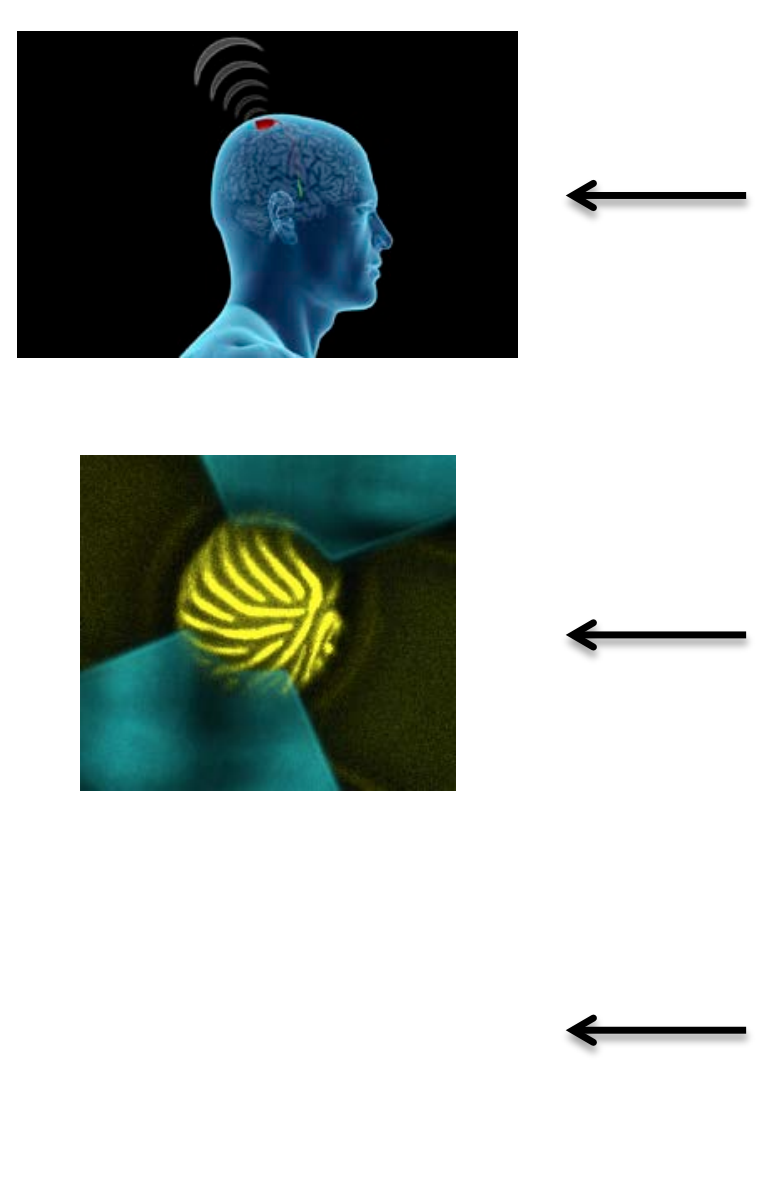

Brophy \& Voigt, 2014

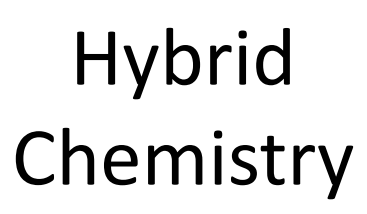

Biological
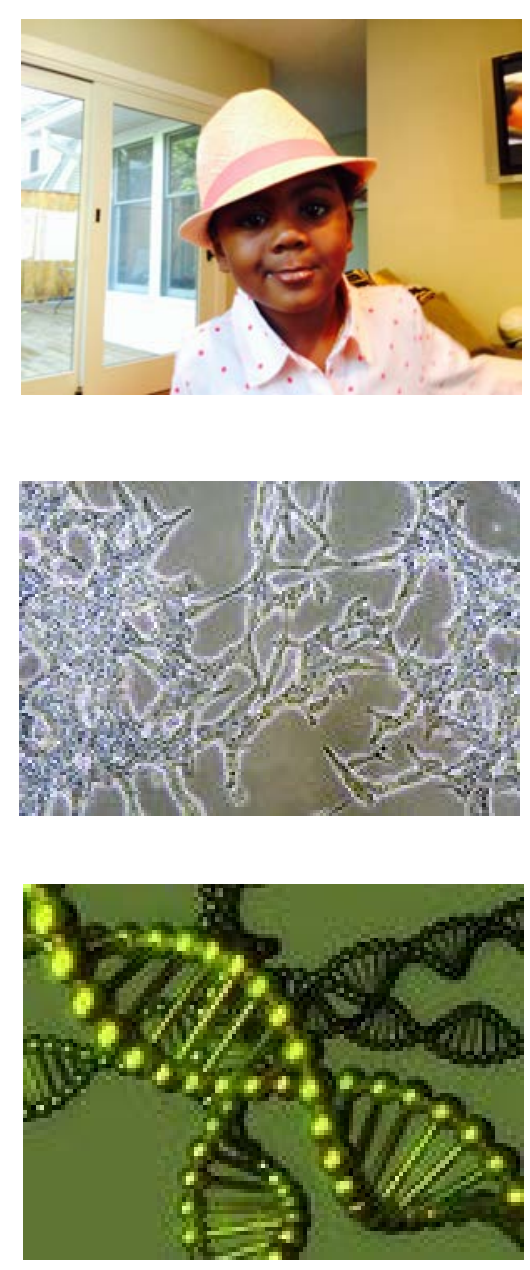

C<smiles>O</smiles>

$\mathrm{N}$ 


\section{Why Hybrid? Why do we need the Bio?}

"Biological engineering is poised to outdo all previous engineering fields"

(1) ability to miniaturize in 3 and 4 dimensions

(2) inherited billions of years of evolutionary innovation and testing an unparalleled list of parts, systems and applications

(3) can combine (1) and (2) to produce accelerated evolution

Moore's Law $\quad \rightarrow \sim 1.5$ fold per year

Rate of biotechnology $\rightarrow \sim 8$ fold per year

George Church, Harvard Foreword to Synthetic Biology: A Lab Manual

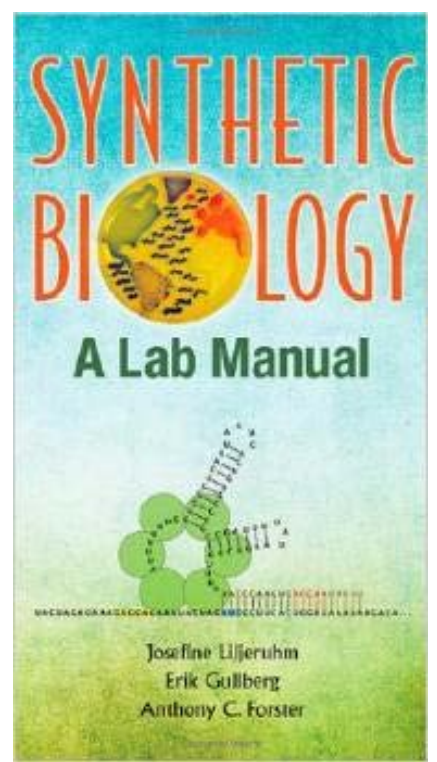




\section{NeuroEngineering $\rightarrow$ Neural Implants}

Science Fiction
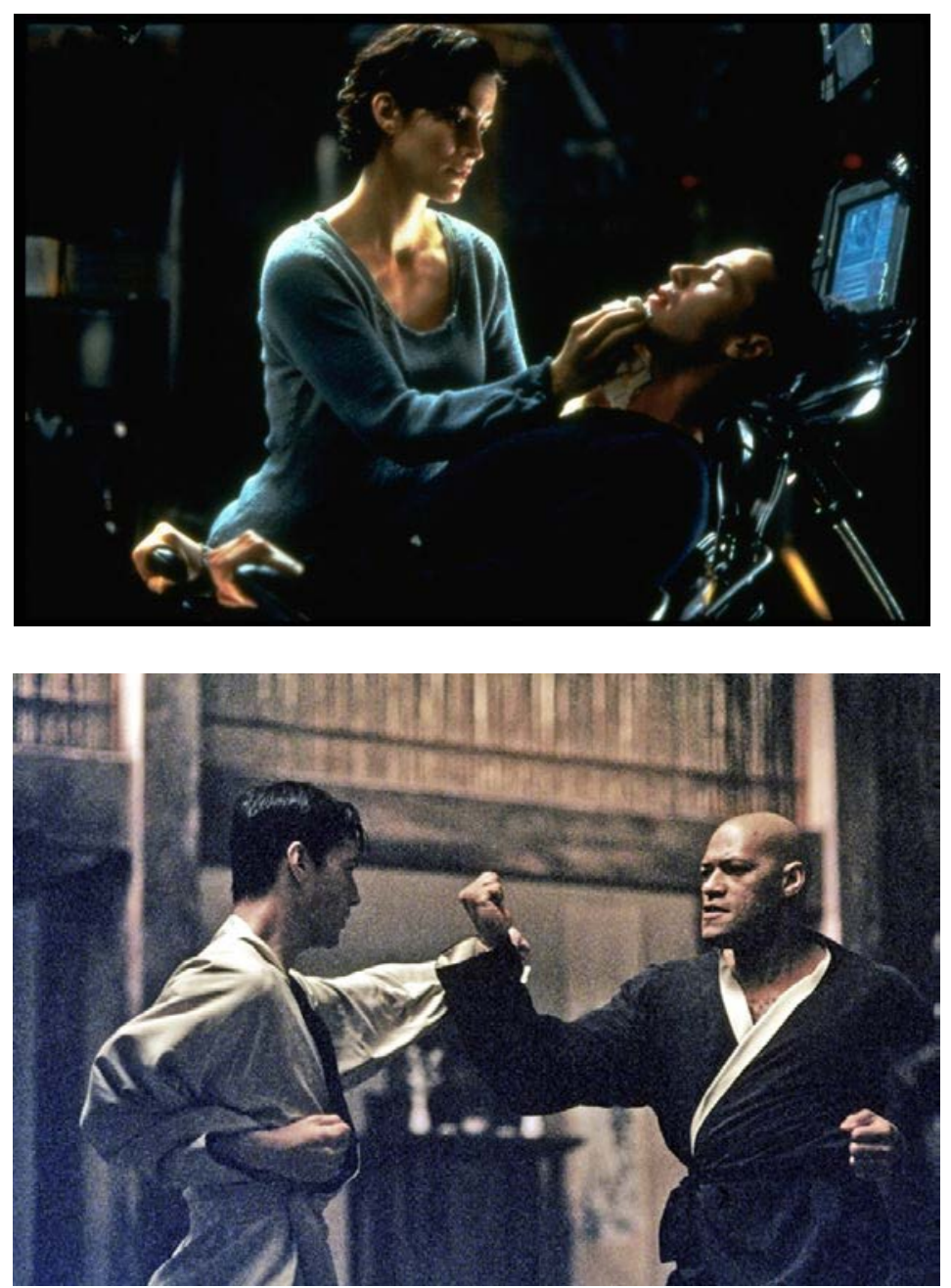

http://discovermagazine.com/2013/march/1-matrix-learning
Science

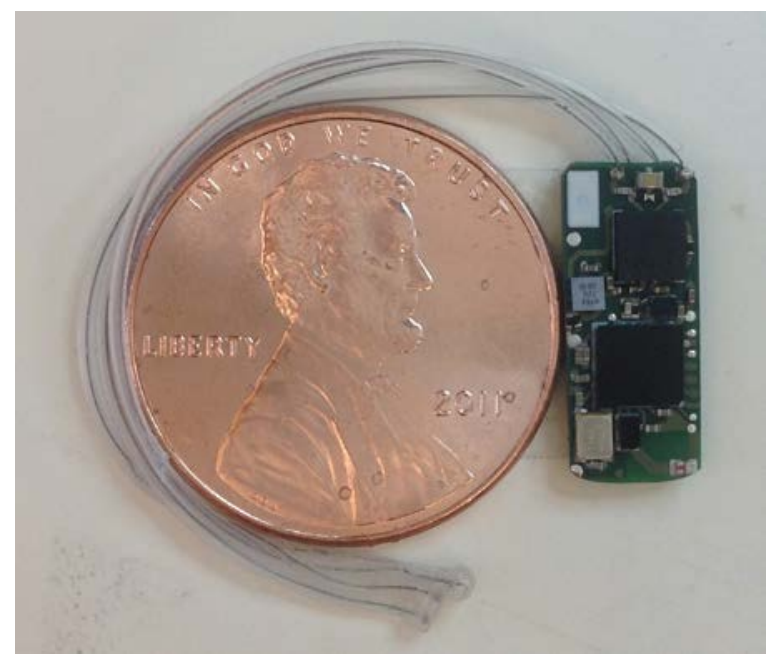

Wireless neural implant Records, Stimulates Up to 8 in one patient

Pedro Irazoqui, Purdue University Center for Implantable Devices 


\title{
NeuroEngineering $\rightarrow$ Neural Implants
}

\author{
Why? \\ Because .... \\ $\sim 1 \%$ of the world has epilepsy \\ $\&$ \\ $30 \%-40 \%$ of patients have drug resistant seizures
}
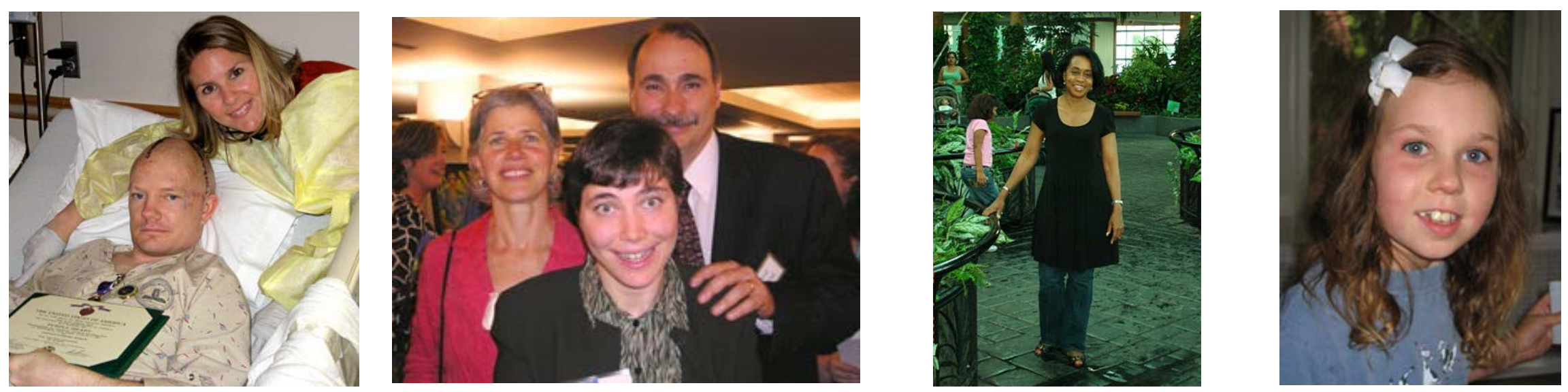

http://www.cureepilepsy.org/ CURE 


\section{NeuroEngineering $\rightarrow$ the Brain Computer Interface}

Science Fiction

AMPed war exoskeleton
Science

Mind-controlled exoskeleton

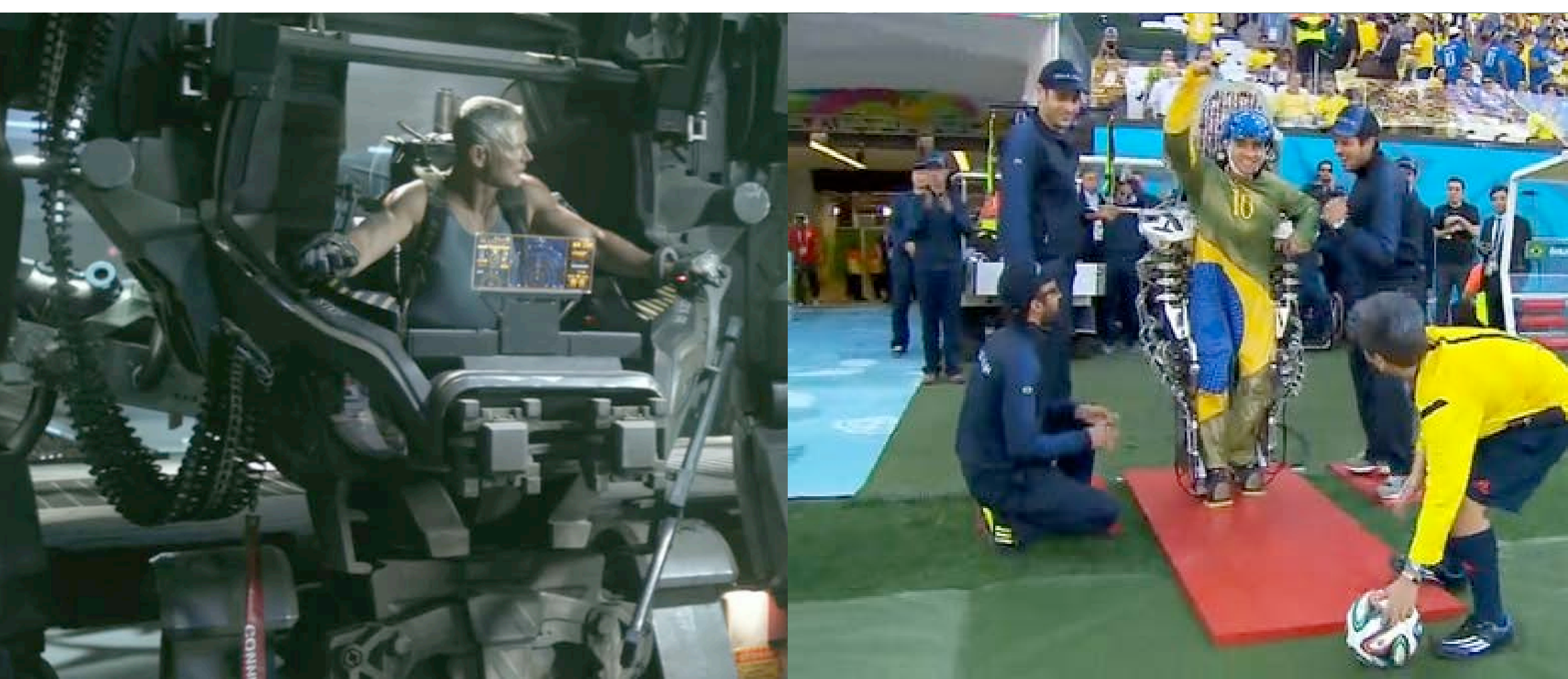




\section{NeuroEngineering $\rightarrow$ the Brain Computer Interface}

\section{Why?}

To restore the ability to experience and engage with the outside world to those who have lost that ability.
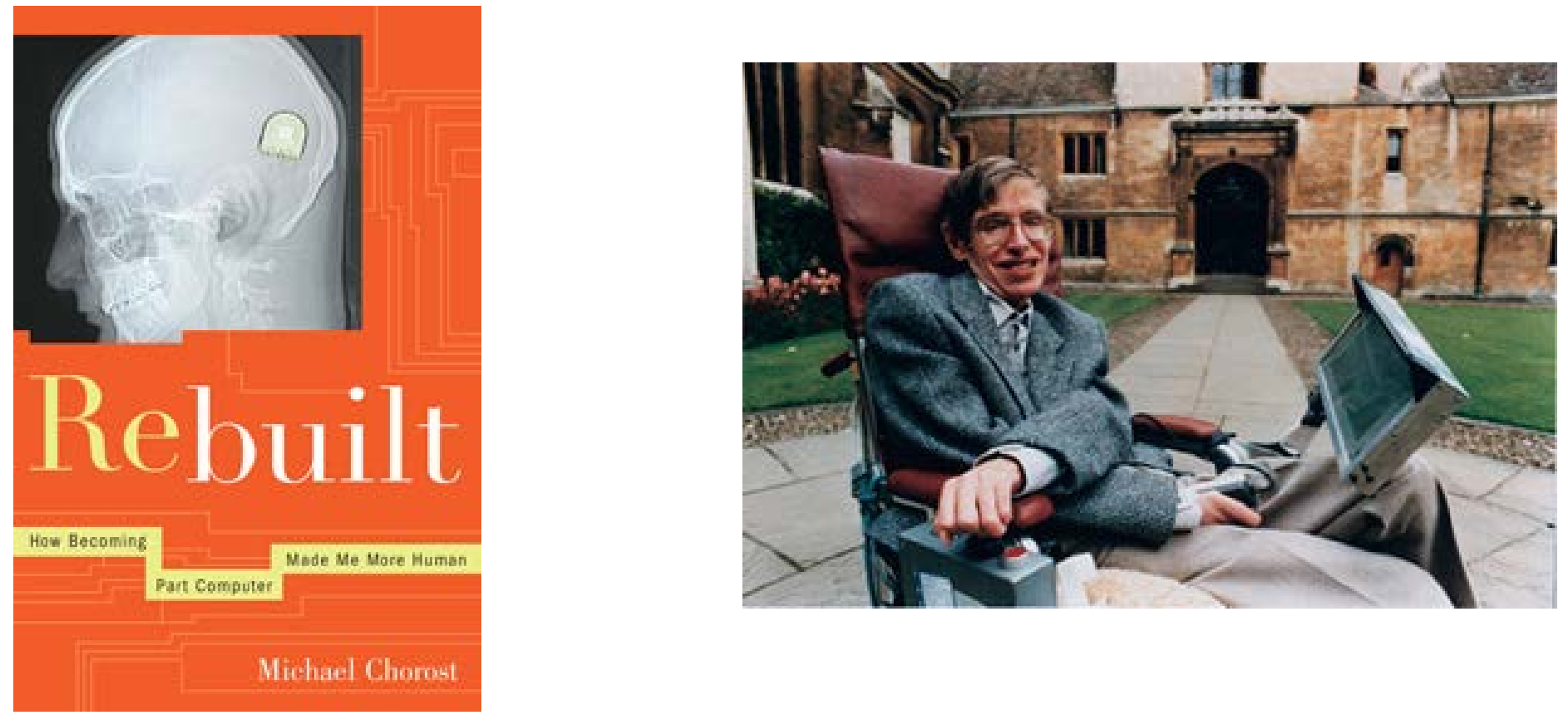


\section{Tissue Engineering $\rightarrow$ Organs in the Lab}

Science Fiction

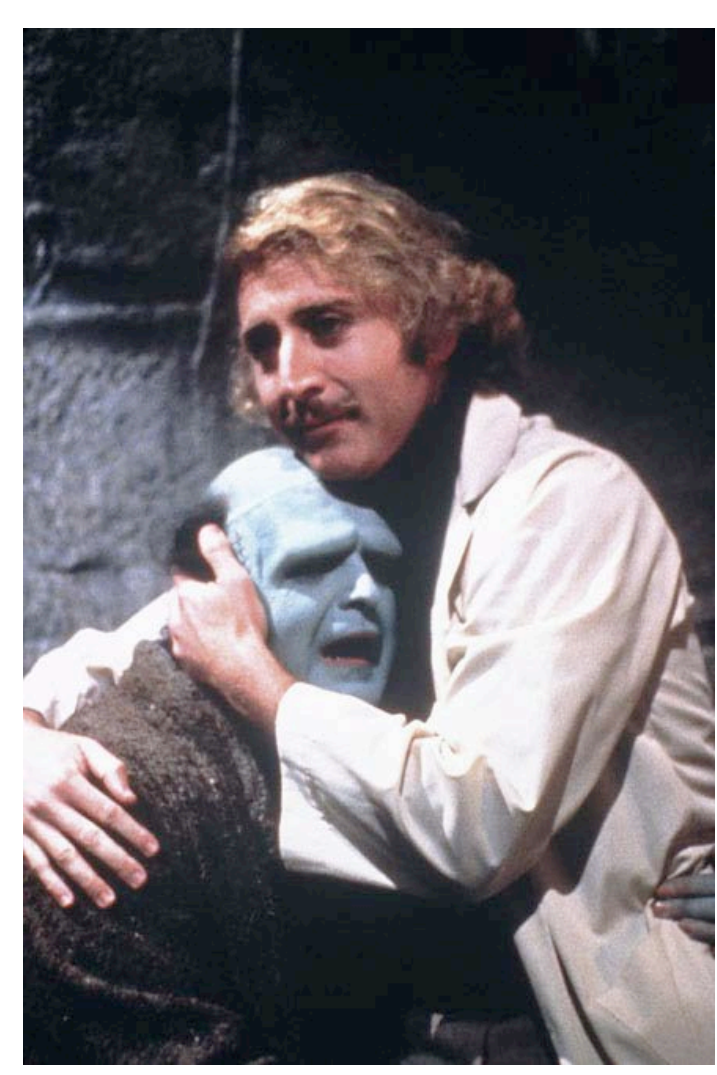

Science

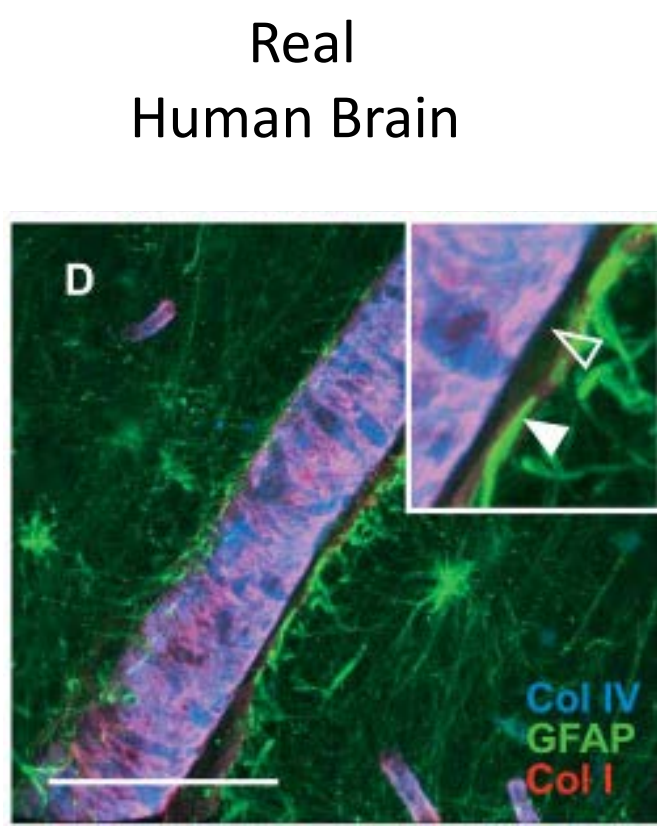

Gritsenko et al 2012
Engineered Human Brain

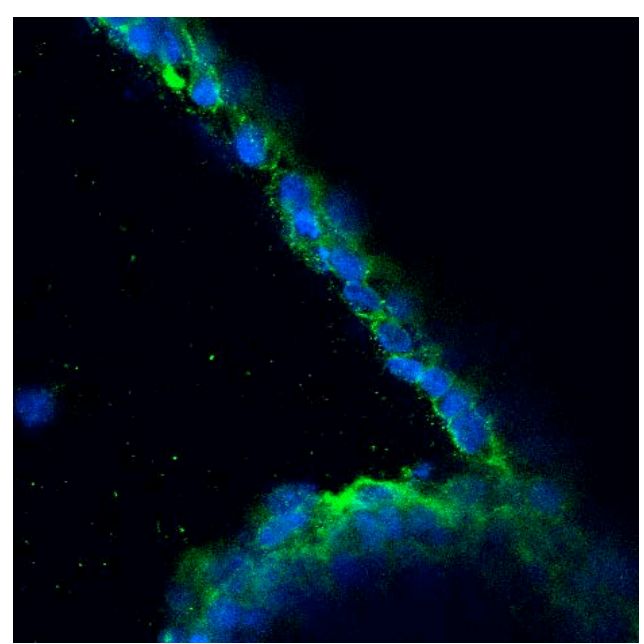

Rickus Lab

Watching tumor cells from a human patient migrate along a pseudo blood vessel in an engineered brain. 


\section{Tissue Engineering $\rightarrow$ Organs in the Lab}

\section{Why?}

Because ...

the median survival after diagnosis with glioblastoma is $15-18$ months

current cell and animal models do not predict therapy outcomes in humans

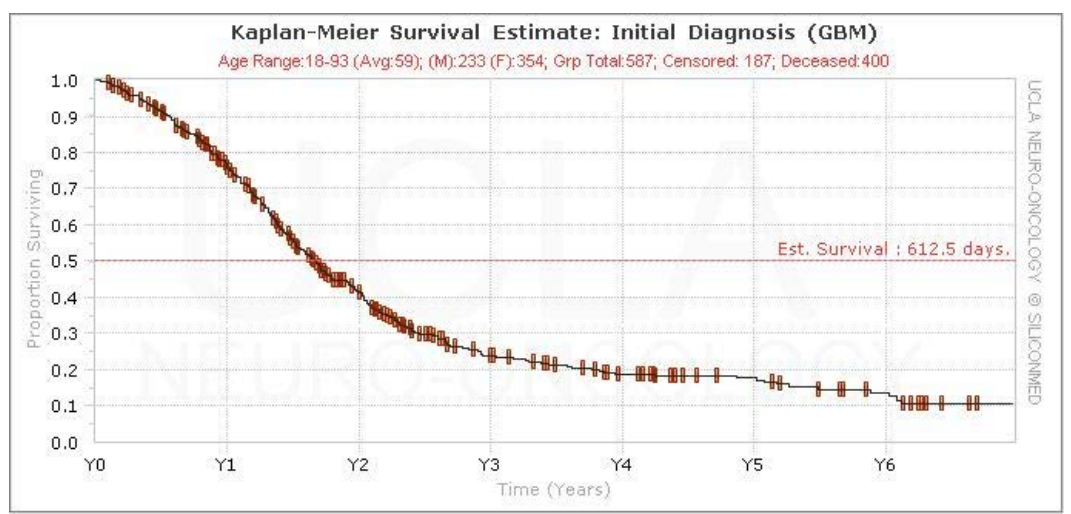

http://www.neurooncology.ucla.edu/Performance/Glioblasto maMultiforme.aspx

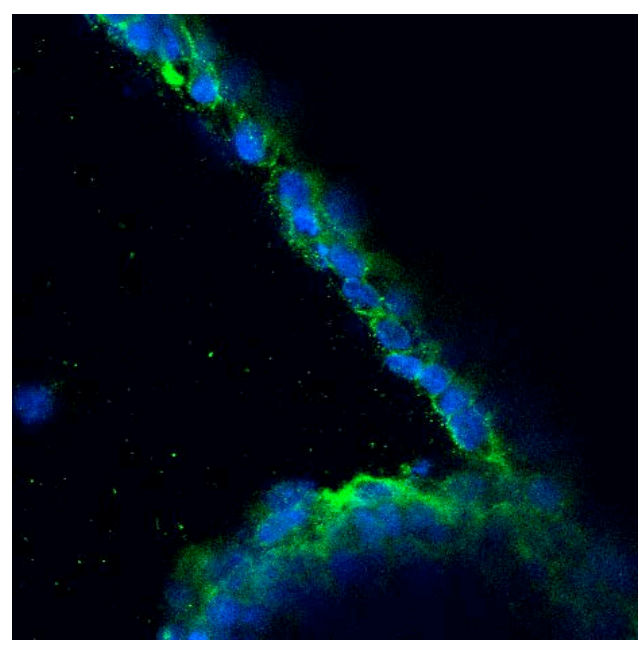




\section{Synthetic Biology $\rightarrow$ Writing Genomes}

Science Fiction

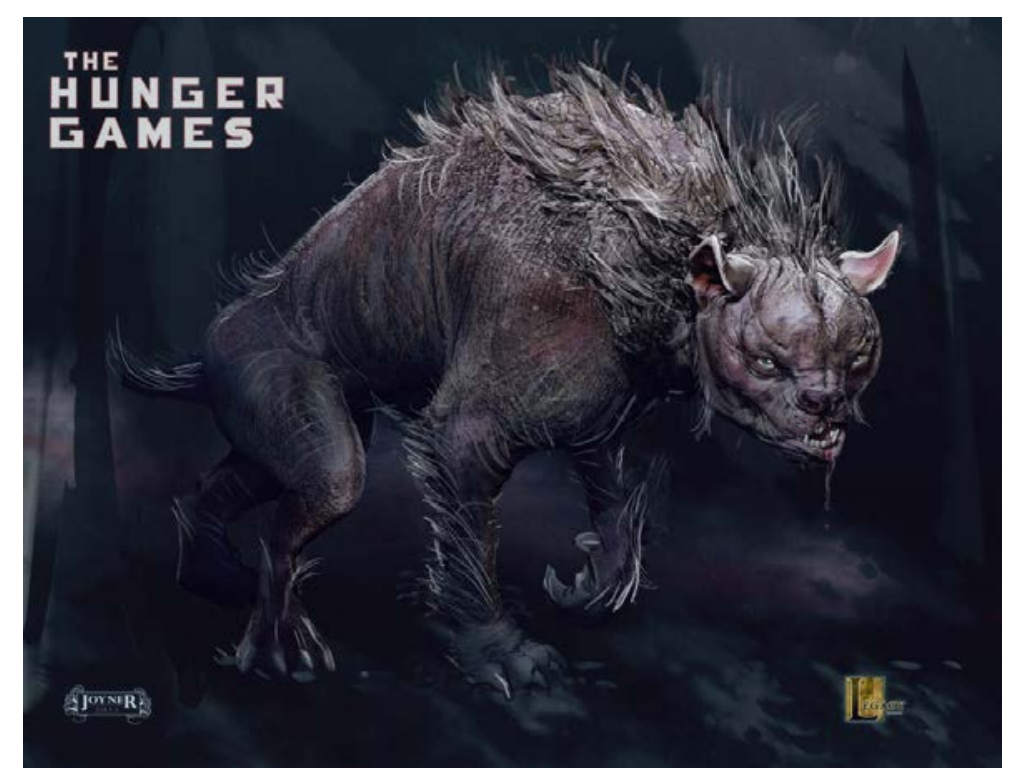

https://thehungergames2012.wordpress.com

\section{Science}

2010 - the first genome transplant of a chemically synthesized genome
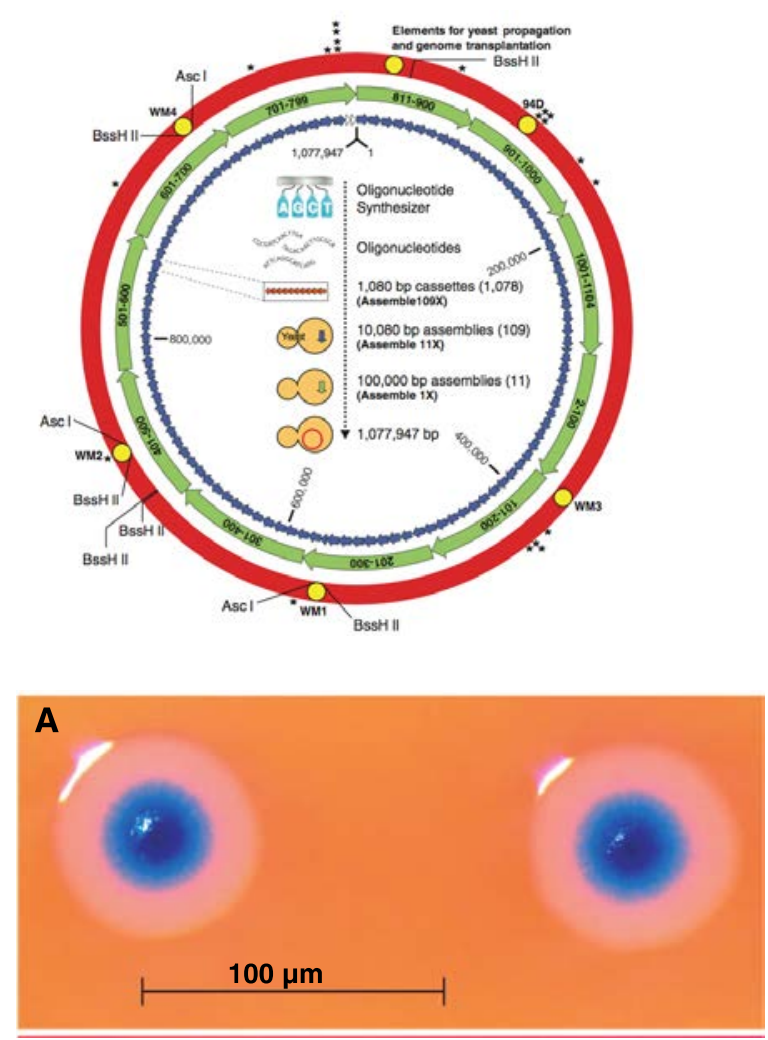

Gibson et al. Science 329, 52 (2010) 


\section{Synthetic Biology $\rightarrow$ Writing Genomes}

Because ...

\section{Why?}

Human global extraction of earth's raw materials is 70 billion metric tons / year
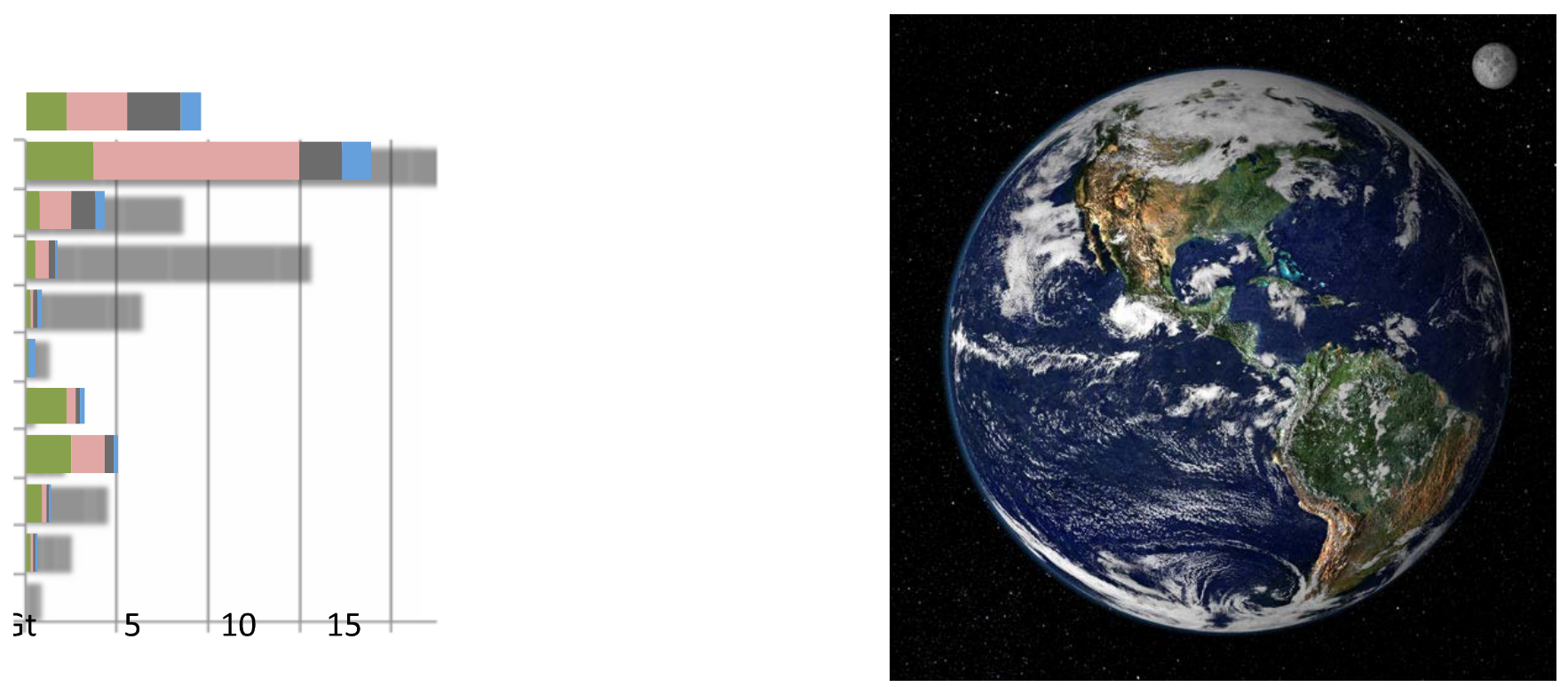


\section{iGEM}

http://igem.org

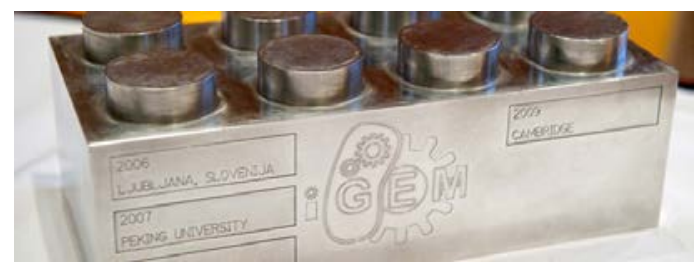

\section{Module 1: Resource-full Waste}

\section{From trash to bioplastic}

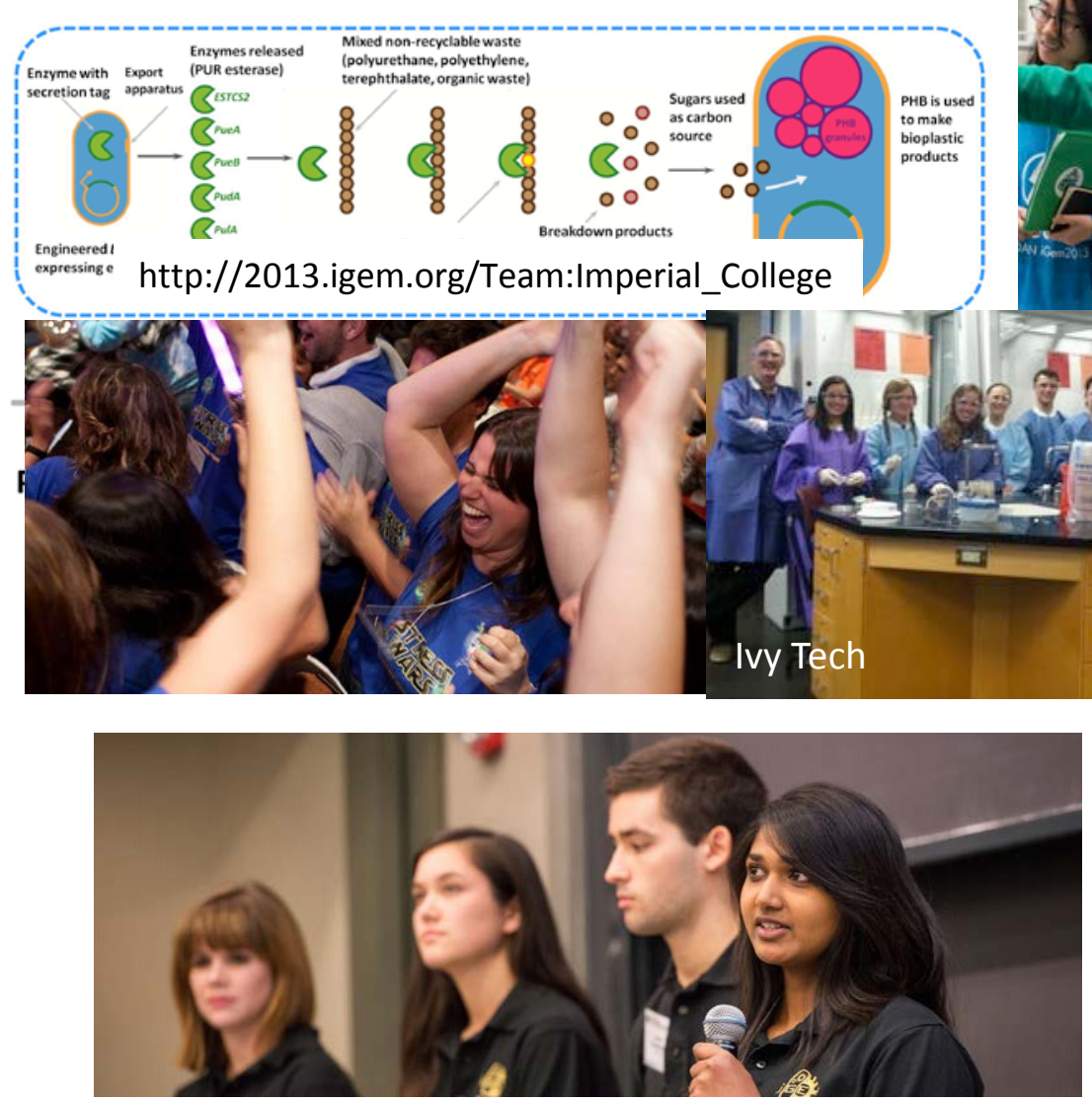

http://2013.igem.org/Team:Purdue
40 HEALTH AND MEDICINE

36 - ENVIRONMENT

31 - NON-SPECIFIED

29 FOUNDATIONAL ADVANCE

25 FOOD AND ENERGY

24 NEW APPLICATION

I3 MANUFACTURING

12 INFORMATION PROCESSING

8 SOFTWARE

4 - ENTREPRENEURSHIP

215 TEAMS

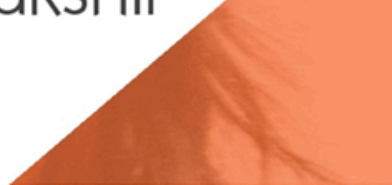

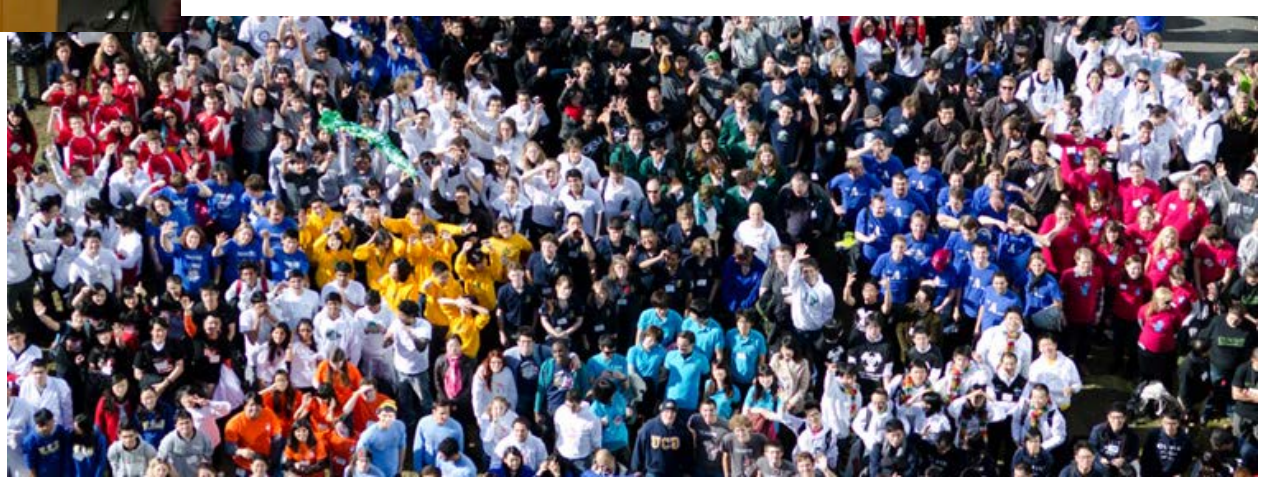




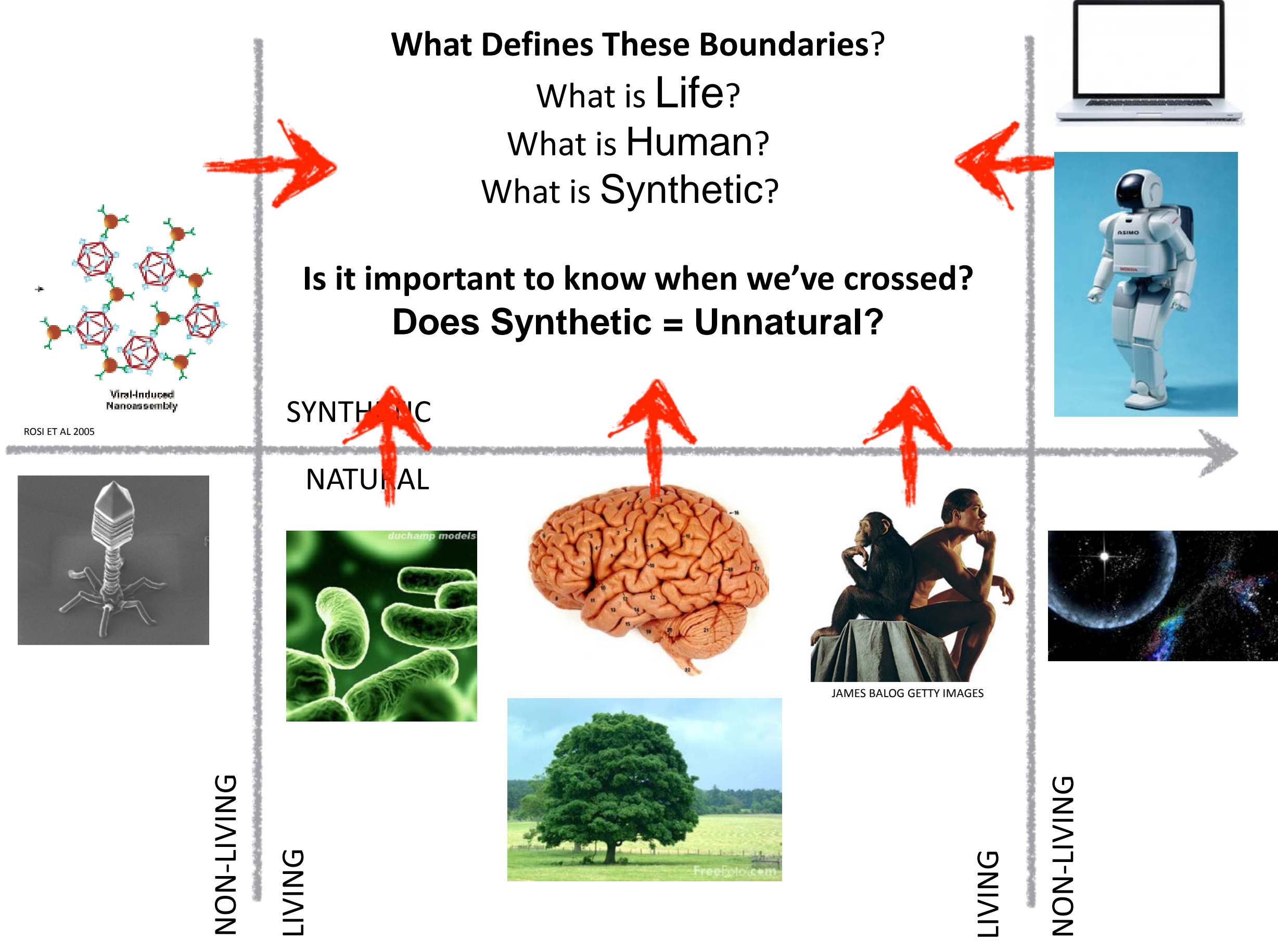




\section{A Working Definition of Life?}

Function

Thermodynamics

Control

Cognitive

Beyond Current Understanding
- Metabolize, Evolve, Replicate

- Decreases the entropy of its own system

- Respond to surroundings

- Strive for conservation

- Goal-oriented

- Self-aware

- Human intellect cannot fathom

- Evaluated on case by case basis

- Life can come in many forms 


\section{A Working Definition of Life?}

Based on your working definition, is the character living?

\begin{tabular}{|c|c|}
\hline Eve & $\begin{array}{c}\text { Representation/simulation of } \\
\text { Jack's dead human wife who } \\
\text { learns, has all old \& makes new } \\
\text { memories }\end{array}$ \\
\hline Jack & $\begin{array}{c}\text { Man whose body has been } \\
\text { replaced with alien form } \\
\text { Can exist with Eve in virtual reality }\end{array}$ \\
\hline $\begin{array}{c}\text { Sink } \\
\text { Ambassador }\end{array}$ & $\begin{array}{c}\text { Alien whose natural form is like } \\
\text { Jack's new form }\end{array}$ \\
\hline $\begin{array}{c}\text { Sculptor } \\
472\end{array}$ & $\begin{array}{c}\text { Alien sentient creature of ice, } \\
\text { helium, hydrogen; on different } \\
\text { time scale }\end{array}$ \\
\hline
\end{tabular}

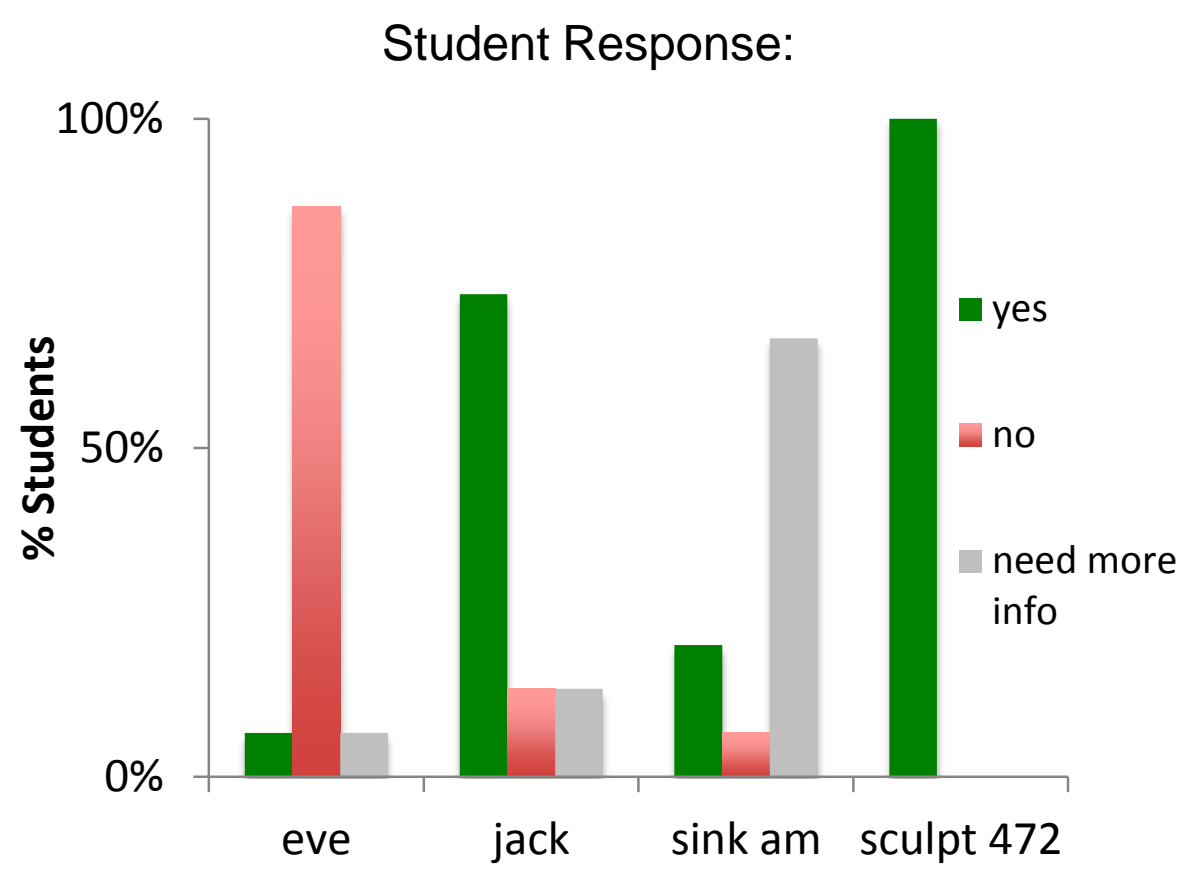

Lessons: Substrate - was less relevant to the students Perspective $-1^{\text {st }}$ person perspective affected opinion 


\section{Synthetic Consciousness?}

Could I assemble a neural construct (from circuits or cells) that attains consciousness? How would I know?

I can't have the $1^{\text {st }}$ person perspective given to me in Vacuum Diagrams.

Reduction - Brain Slice

When is consciousness lost?

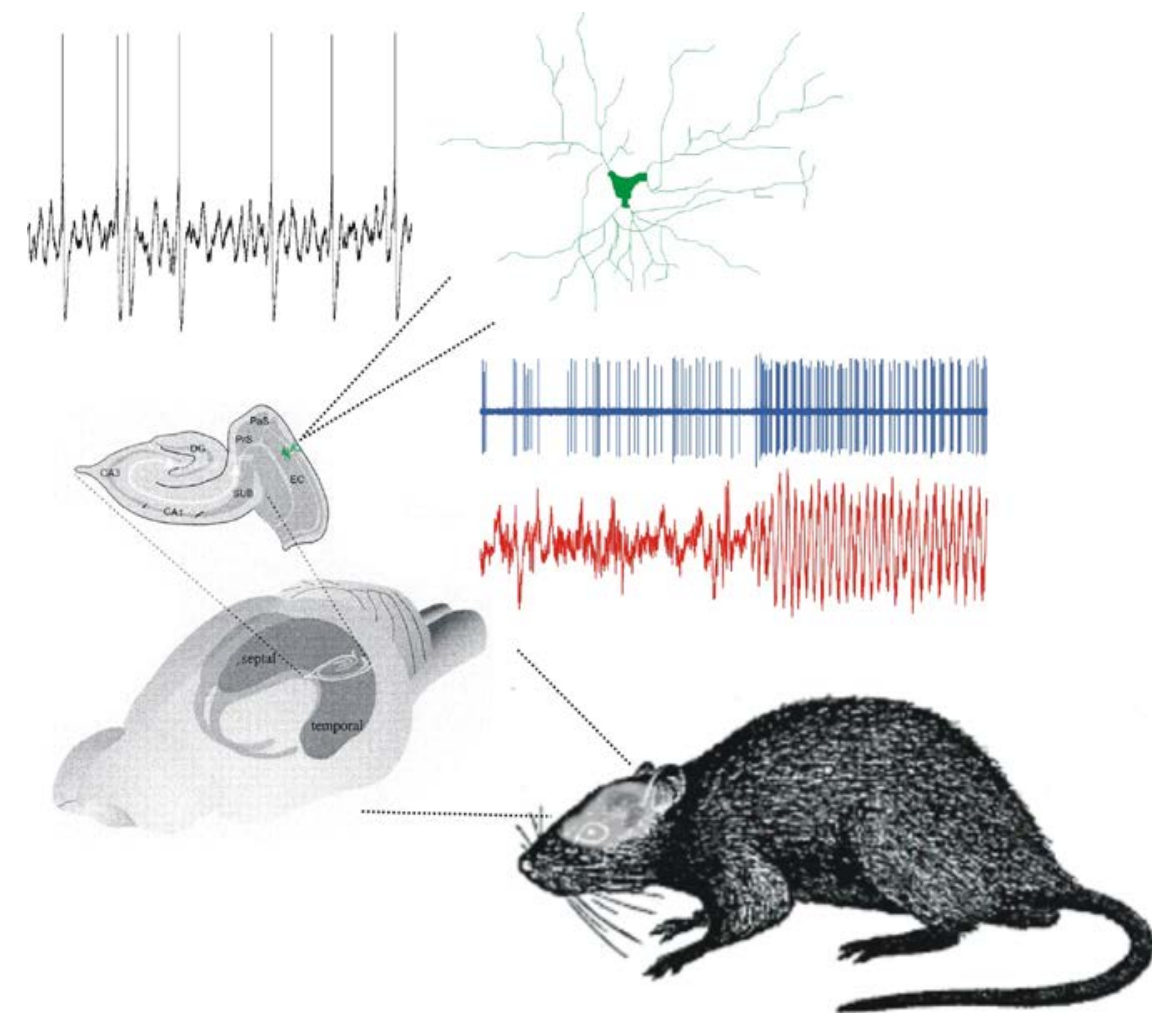

http://www.psych.ualberta.ca/ cdickson/facilities.html
Construction - Engineered Cortex When does consciousness emerge?

A a
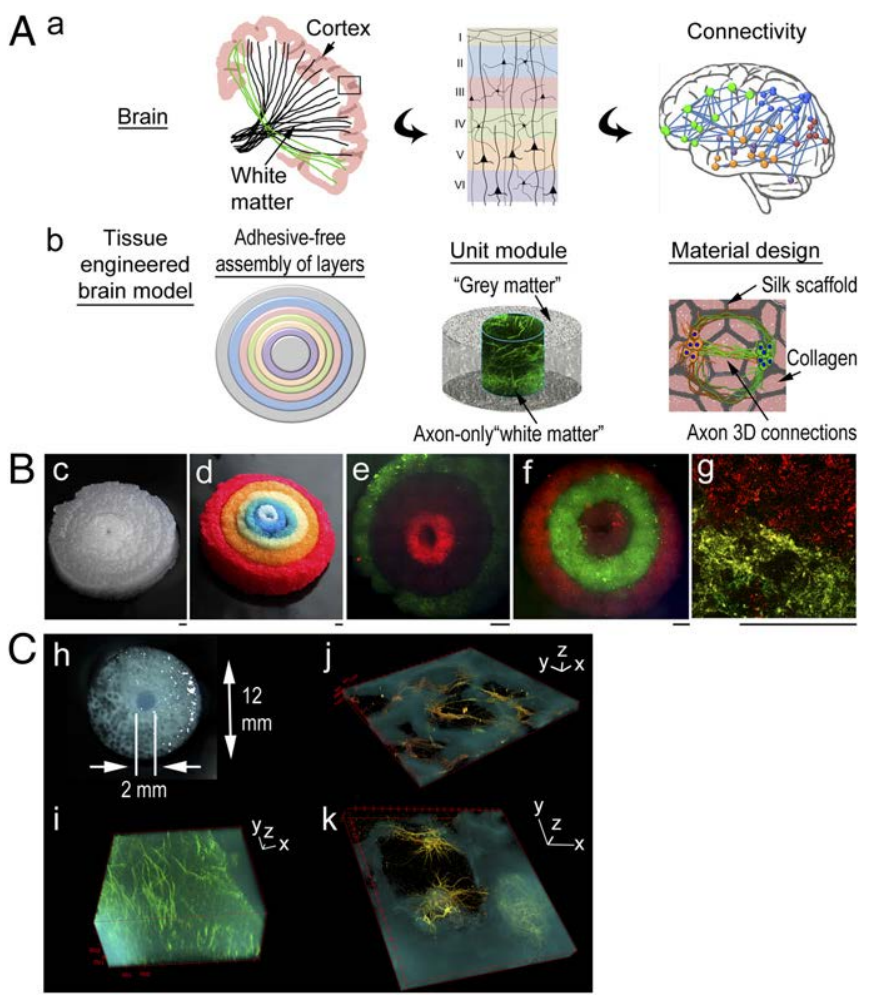

http://www.pnas.org/content/early/2014/08/06/1324214111 


\section{What makes us human?}

hardware: Is humanity in the biological substrate?

software: Is humanity in the input output functions and interaction with the outside world and other people?

When are we modified to a point that we are Synthetic?

Synthetic manipulation of higher function?
Memory
Emotion
Attention

What then about
Identity
Free Will
Responsibility 


\section{In the Context of Al and Superintelligence}

\section{Beyond Brain Machine Interface Workshop: From Senses to Cognition}

(Sponsored by Army Research Office and IEEE EMBS)

Brain-machine interfaces (BMI) have inspired popular culture and captured the imaginations of scientists and non-scientists alike. This relatively new field emerged in the 90's with the primary aim of replacing or augmenting communication channels in the severely paralyzed. Since then, developments in neuroscience, neural interface technology, and algorithms have led to rapid progress in diverse areas such as neural, speech and visual prosthetics to name a few. As with the field of neuroprosthetics, which has reached critical mass, it seems inevitable that the use of brain-controlled devices will extend beyond clinical need into cognitive and physical augmentation of healthy individuals.

Spring 2010

Might the path to super-intelligence be to make humans part computer?

Human-Computer Hybrids? 


\section{Common Risks / Concerns}

- Biosecurity: Bioterrorism \& War

- Biosafety: Bioerrorism

- Modified or Synthetic Organisms will Escape

- Al will escape and out-think \& destroy us

- Accidental exposure

- Environmental

- Biology is unpredictable - Wreak Havoc

- Further separates humans from nature

- Its Unnatural

- Abominations
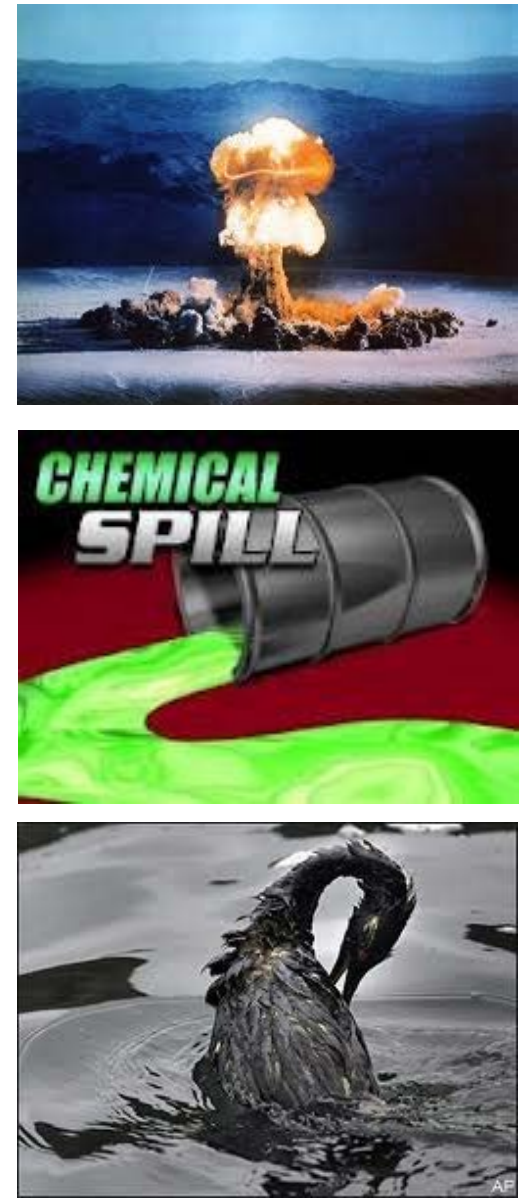

MONSTIBR COLLECHON

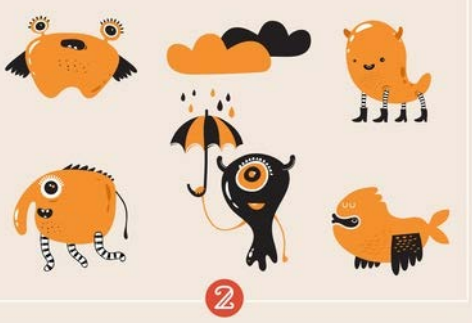




\section{Technology \& Destruction}

- With human progress $\rightarrow$ violence has decreased we are less likely to die at the hands of another human

http://www.ted.com/talks/steven_pinker_on_the_myth_of_violence

- "increasing lethality of our hatred"

a few are more capable of killing many

http://www.ted.com/talks/robert_wright_on_optimism

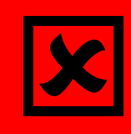

- $\mathrm{Al}$, brain-computer interface, synthetic biology

give us new ways to kill each other and ourselves

- Cannot forget natural possibilities for extinction technology may be our best hope to fight infectious disease 1918 Spanish Influenza infected 1/5 of the world's population doing nothing is a choice that has risk

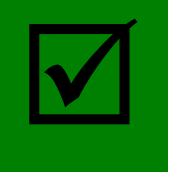




\section{Myth of Technological Determinism}

\section{Technology is ...}

- primary governing force for societal change

- shapes a society's values, social structure, and history.

\section{Social progress ...}

- is driven by technological innovation

- therefore follows an "inevitable" course. 


\section{Myth of Technological Determinism}

- Implicitly embedded collective memory and historical teachings

- Eli Whitney $\rightarrow$ Cotton Gin $\rightarrow$ Slavery Grew $\rightarrow$ Civil War

- Gutenberg $\rightarrow$ Printing Press $\rightarrow$ Bibles in Hands $\rightarrow$ Fueled Reformation

- Jenna Rickus $\rightarrow$ artificial brain tissue $\rightarrow$ cure brain tumors $\rightarrow$ global peace

- "Technology suddenly appears and important things happen"

- Genius inventor

- "consequences rather than the genesis of the invention"*

- Problem

- Decouples average citizen from technology development

- Ignores the societal forces that drove the technology

- Leaves us feeling outcomes are inevitable

* “Does Technology Drive History? The Dilemma of Technological Determinism?" Smith \& Marx. 1994. MIT Press

The National Academies. 2010. http://www.nae.edu/nae/techlithome.nsf/weblinks/KGRG-569LNP?OpenDocument 


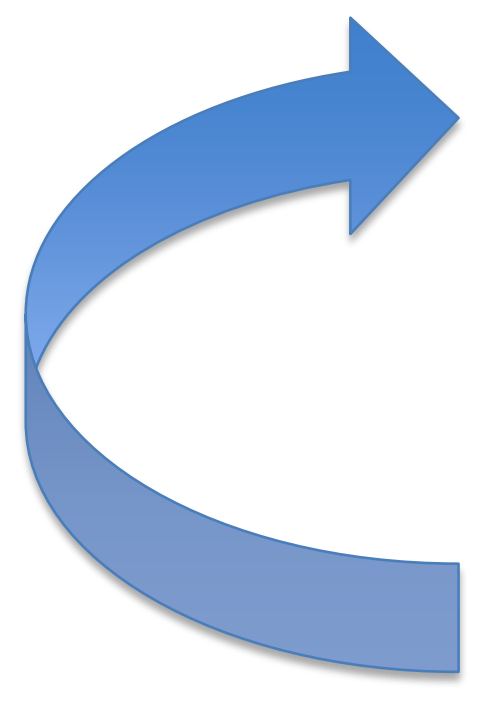

\section{TECHNOLOGY}

\section{SOCIETY}

ACTION: Improve Technical Literacy of Citizens

http://www.nae.edu/nae/techlithome.nsf/weblinks/KGRG-569LNP?OpenDocument

ACTION: Work on the Hatred, Keep Technology Moving Forward

http://www.ted.com/talks/robert_wright_on_optimism

ACTION: Engineers need to understand societal forces driving technology 


\section{Does Synthetic = "Unnatural"?}

People feel strongly but cannot always articulate why

Do you view humans as $\square$ equal member, part of "nature"?

$\square$ unique, dominant over, external to "nature"?
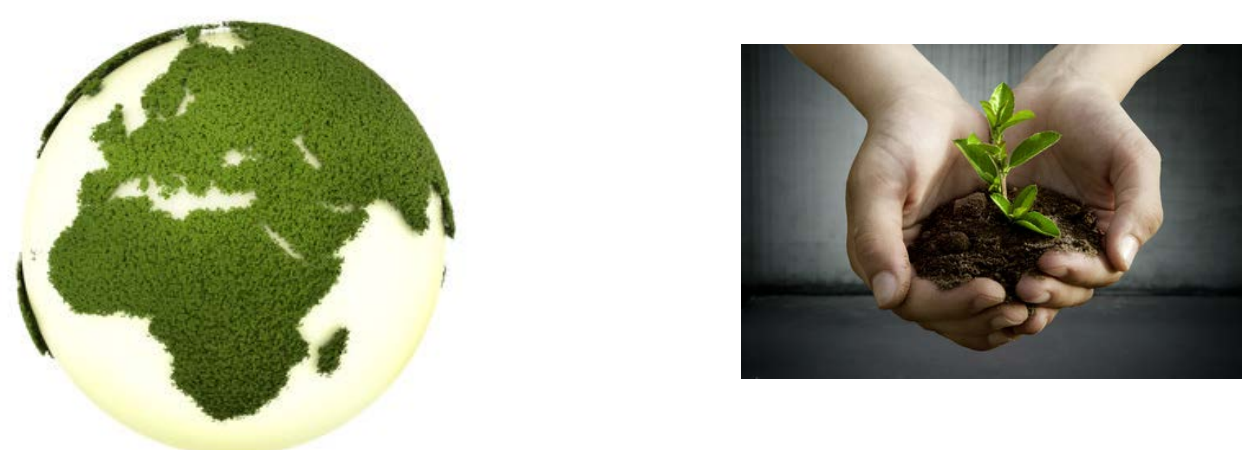

Extreme 1

Technology = Human Evolutionary Advantage. What we have evolved to do to survive.

- All synthetic life

- technology is natural. http://howardbloom.net
Extreme 2

We are arrogant to think we have the right to engineer life.

- All synthetic life

- technology is unnatural

Religious, Scientific, Personal Backgrounds inform this world view but not science versus religion Many gradations between the extremes 


\section{Many Directions for Conversation and Study that I did not Cover}

Cognitive Illusions influence Risk Assessment of Technologies and Decision Making

Ethical Frameworks

testing sufficiency of our bioethics frameworks (e.g. Principlism) for synthetic life and hybrid technologies.

Global Oversight of Technology

Laws and regulations are federal but Impact and reality is global

Moral Status

modified and synthetic organisms and humans 


\section{Thank You!}

\section{Continue the Conversation!}

text $\mathbf{M 5 6 7 2}$ + your message 